\title{
New agreement adds zest to US - Soviet exchange
}

\section{- Glasnost rampant in the academies - Greater access to scientific data assured}

\section{Washington}

RIDING high on a wave of goodwill between their respective countries, the US National Academy of Sciences and the Academy of Sciences of the USSR on 12 January in Moscow signed a 5-year agreement that will permit a vastly expanded level of scientific cooperation between the two countries.

The new agreement calls for more individual scientific exchanges, scientific workshops and collaborative projects. It supersedes the two-year agreement between the two academies that would have expired later this year.

The signing comes on the heels of a successful meeting between members of the US and Soviet academies during last month's summit meeting between President Ronald Reagan and General Secretary Mikhail Gorbachev.

National Academy of Sciences president Frank Press says that the openness of the Soviet academy members dazzled their US counterparts. "It was almost like visiting another Western country", Press said last week after his return from Moscow. Particularly noteworthy was the availability of unexpurgated Western scientific journals, such as Nature.

The new agreement will be evaluated after two years to see what changes, if any, need to be made. In the initial years, exchanges of scientists will take place at the same rate as at present - up to 50 person-months a year - but Press says this will be allowed to increase if there is a greater demand. The exchanges will not be restricted to academy members, but will involve scientists chosen for accomplishments in their respective fields.

There will be up to eight workshops in the first two years of the agreement, four in each country. The proposed topics include non-linear systems in the prediction of earthquakes, vaccine development, dynamical symmetries and supersymmetries, and astrophysics. In addition, the agreement calls for cooperative research efforts on subjects ranging from condensed matter theory to nuclear reactor safety.

Press believes a significant accomplishment of the new agreement will be to permit summer workshops aimed at scientists under 30 years old. He says that the inclusion of such young people in international exchanges is unprecedented for the Soviet Union. Press is also enthusiastic about the new access US scientists will be granted to facilities not associated with the Soviet Academy, including universities.

Although issues of human rights remain, Press says Soviet academicians have shown themselves to be effective at ameliorating violations. At a press conference in Moscow after the signing of the agreement, Soviet Academy president Guriy Marchuk said no one would be forced to stay in the Soviet Union.

It is clear that fabulous fortunes will not be made under the terms of the new agreement. A visiting Soviet scientist will receive a per diem allowance of $\$ 25$ for short visits, or $\$ 500$ per month for stays longer than 3 months. A US scientist visiting the Soviet Union will receive 20 roubles a day for short stays, and 400 roubles a month for longer visits.

Joseph Palca

\section{Problems of Soviet defector}

\section{New Delhi}

INDIA, Australia and the Soviet Union are involved in a diplomatic tangle over the defection of a Soviet biologist who arrived in India as a member of a tourist group. Babi Alexandra, a 25-year-old Jew, left the group during a shopping trip on 18 December to seek asylum at the Australian High Commission.

The future of the Soviet scientist remains uncertain while Australia continues diplomatic talks with the Soviet Union and Indian governments. Alexandra would have been in Austrailia by now but for the Indian law that a request for asylum on Indian soil from a citizen of a third country has to go through a judicial process. But once Alexandra steps out of the Australian High Commission, police will hand him over to the Soviet Embassy, which has lodged a complaint over his disappearance. Meanwhile, attempts by the Australian High Commission to get the Soviet tourist the status of a refugee have so far evoked no response from the New Delhi office of the UN High Commissioner for Refugees

Everything points to Alexandra's being deported. In 1985, Igor Geza, from the Soviet Embassy in New Delhi, disappeared only to reappear in the United States a week later. In the 1960 s, Stalin's daughter Svetlana defected to the West from New Delhi.
K.S. Jayaraman

\section{Nuclear explosions}

A NEW study by the National Resources Defense Council (NRDC) shows that there were 71 unannounced nuclear explosions at the Nevada Test Site between 1963 and 1978. NRDC says this figure provides the first clear picture of the true size of the US testing programme.

The new estimates were prepared by an examination of seismic records collected at the Seismological Laboratory at the California Institute of Technology in Pasadena by Riley Geary. NRDC figures suggest that the United States has conducted a total of 919 nuclear weapons tests since July 1945, 117 more than have been publicly announced.

J.P.

\section{Out to get him?}

HugH DeWitt, a physicist at the Lawrence Livermore National Laboratory and an outspoken critic of US nuclear weapons-testing policy, is disputing an unfavourable performance evaluation of his work at the laboratory. DeWitt believes that the evaluation may be the harbinger of an attempt to dismiss him.

He has written to David Gardner, president of the University of California, which runs the Livermore Laboratory, to protest at the evaluation. DeWitt says the laboratory has never been happy with his criticism (see Nature, 329, 275; 1987), but feels that unhappiness has increased in the past year, leading to the unfavourable review.

J.P.

\section{Research ships Finnish}

FINLAND's Rauma-Repola company last month formally handed over to the Soviet Union two deep-water research vessels, capable of operating at depths of up to $6,000 \mathrm{~m}$, some $2,000 \mathrm{~m}$ deeper than the present limit.

The vessels, built of specially strengthened steel, were designed by a joint FinnishSoviet team and built in secret at the Finnish yard over the past six years. Each vessel can carry a crew of three and can operate independently of the mothership for up to four and a half hours. The speed and power capacity of their batteries is said to be twice as great as those of the United States Sea Cliff and the French Nautilus vessels.

V.R.

\section{Pin-ups banned}

POSTERs and magazines portraying images of women should be banned from observatories and astronomical facilities, according to a letter published in the latest Newsletter of the American Astronomical Society. The letter, signed by 42 astronomers in the Five College Radio Astronomy Department at the University of Amherst, Massachusetts, describes such material as a form of sexual harassment whose presence "creates a hostile work environment for women".

P.C. 